\title{
USAHA-USAHA MEMASYARAKATKAN HUKUM DI DALAM MASYARAKAT*
}

\author{
Arpan Zaman \\ Institut Agama Islam Negeri (IAIN) Kerinci \\ Sungai Penuh Kerinci Jambi Indonesia \\ e-mail: arpan17zaman@gmail.com
}

\begin{abstract}
This research was discussed about the way to socialize law in the society such as law education and how to maintain the law in the right place such as law education, law knowledge, society understanding about law, law structure, law culture and law substance. Besides, this research aims at knowing about the obstruction in socializing. This research was a library research by describing the problems with the relevant theories. The result of this research shows that in socializing the law in the society, it needs a lot of things to be done such as, willingness, education, supports from the environment, custom and culture, and awareness to obey toward the law in the society sincerely without any force. Furthermore, counseling, socialization and seminar are the way to make it easy in socializing the law in the society. Whereas, the obstruction in socializing the law are dominated by the level of education and knowledge had by the society, custom and culture in that place that is grew and developed, law structure, apparatus and law substance.
\end{abstract}

Keywords: Law, Society

\begin{abstract}
Abstrak
Artikel ini membicarakan cara memasyarakatkan hukum di dalam masyarakat seperti pendidikan hukum dan bagaimana seharusnya hukum itu ditegakkan pada tempat yang sesuai serta usaha menegakkan hukum dengan caranya seperti pendidikan hukum, pengetahuan hukum, pemahaman masyarakat tentang hukum, struktur hukum, dan budaya terhadap hukum, serta substansi hukum. Di samping itu, tulisan ini bertujuan untuk mengetahui hambatan di dalam memasyarakatkan hukum. Penelitian ini menggunakan penelitian kepustakaan dengan menggambarkan masalah dengan relevansi teori. Hasil yang ditemukan dalam penelitian ini membuktikan bahwa dalam usaha memasyarakatkan hukum di dalam masyarakat dibutuhkan banyak hal di antaranya: kemauan dan rasa ingin tahu, pendidikan, dukungan dari lingkungan, adat dan budaya serta kesadaran untuk taat dan patuh terhadap hukum yang berlaku di masyarakat dengan ikhlas dan tanpa paksaan dari siapapun. Selain itu, penyuluhan, sosialisasi dan seminar menjadi alat untuk memudahkan memasyarakatkan hukum di dalam masyarakat. Sedangkan hambatan dalam usaha memasyarakatkan hukum di dominasi oleh tingkat pendidikan dan pengetahuan yang dimiliki oleh masyarakat, adat dan budaya setempat yang tumbuh dan berkembang dan struktur hukum, serta aparatur penegak hukum itu sendiri dan substansi hukum.
\end{abstract}

Kata kunci: Hukum; Masyarakat

\footnotetext{
${ }^{*}$ Naskah diterima: 20 Oktober 2017, direvisi: 14 Februari 2018, disetujui untuk terbit: 3 Maret 2018
} 


\section{PENDAHULUAN}

Di dalam artikel ini kita akan membicarakan persoalan cara memasyarakatkan hukum di dalam masyarakat yaitu seperti pendidikan hukum di dalam masyarakat. Di dalam pelaksanaan hukum pendidikan hukum sangat diperlukan karena jika masyarakat tidak tahu akan hukum maka suatu hukum itu tidak akan berjalan dengan lancar atau seperti mana yang dikehendaki. Di dalam hukum jelaslah pendidikan, pemahaman dan pengetahuan hukum sebetulnya menjadi dasar bagi penegakan hukum sebagai proses. Pelaksanaan hukum sudah jelas melibatkan antara manusia dan tingkah lakunya. Sedangkan aparat penegak hukum diberi tugas untuk menangani pelanggaran dari pada orang yang melanggar hukum. Penegakan hukum di mana kita mengetahui bahwa penegakan hukum di Indonesia sering disalahgunakan oleh lembaga hukum yang lebih banyak melihat atau menjadikan hukum sebagai pilihan untuk memandang hukum itu dengan pandang bulu. Di dalam tulisan ini akan membahas bagaimana seharusnya hukum itu di tegakkan pada tempat yang sesuai. Penegakan hukum bisa dijadikan sebagai sistem pengendalian kejahatan yang akan menjadikan seseorang itu terhindar dari tingkah laku yang tidak baik untuk dilakukan. Usaha penegakan hukum di dalam tulisan ini kita akan menemukan apa saja usaha-usaha menegakkan hukum dengan cara-caranya seperti pendidikan hukum, pengetahuan hukum, pemahaman masyarakat tentang hukum, struktur hukum, dan budaya terhadap hukum, serta substansi hukum. Di samping beberapa hal yang dikemukakan sebelumnya, tulisan ini bertujuan untuk mengetahui bagaimana cara memasyarakatkan hukum di dalam masyarakat dan juga untuk mengetahui apa yang menjadi hambatan dalam memasyarakatkan hukum di dalam masyarakat.

Usaha-usaha memasyarakatkan hukum di dalam masyarakat akan terwujud apabila memiliki pendidikan hukum, pengetahuan hukum, sikap hukum, dan perilaku hukum yang patuh terhadap hukum. Secara teori inilah yang dapat dijadikan tolak ukur dari memasyarakatkan hukum di dalam masyarakat, karena jika pendidikan hukum, pengetahuan hukum, sikap hukum dan perilaku hukumnya rendah maka kesadaran hukumnya rendah atau sebaliknya. Pendidikan, pengetahuan dan pemahaman hukum yang rendah atau tinggi pada masyarakat mempengaruhi pelaksanaan hukum. Pendidikan, pengetahuan dan pemahaman hukum yang rendah akan menjadi kendala dalam pelaksanaan hukum, baik berupa tingginya tingkat pelanggaran hukum maupun kurang berpartisipasinya masyarakat dalam pelaksanaan hukum.

Selanjutnya, Kemauan dan rasa ingin tahu merupakan dua hal yang harus dimiliki oleh seseorang (subjek hukum) untuk bisa menumbuh-kembangkan hukum yang berlaku di masyarakat, karena dengan rasa ingin tahu dan juga kemauan itulah yang menjadi dasar seseorang untuk bisa mengetahui hukum 
yang berlaku di masyarakat. Pendidikan adalah hal yang sangat menentukan akan pemahaman dan pengetahuan akan hukum yang sebenarnya, walaupun rasa ingin tahu dan kemauan sangat tinggi dimiliki oleh subjek hukum tanpa pendidikan maka hakikat dari hukum yang sebenarnya akan sulit untuk diketahui.

Pendidikan merupakan corong bagi individu untuk mempelajari, memahami dan mengamalkan ilmu sesuai dengan fungsi dan tujuan hukum itu sendiri, adapun yang menjadi fungsi hukum adalah selalu mengikuti serta melekat pada manusia yang bermasyarakat. Hukum memiliki fungsi: menertibkan dan mengatur pergaulan dalam masyarakat serta menyelesaikan masalah-masalah yang timbul. Dalam perkembangan masyarakat. Fungsi hukum terdiri dari: (1) Sebagai alat pengatur tata tertib hubungan masyarakat. Hukum sebagai norma merupakan petunjuk untuk kehidupan manusia dalam masyarakat, hukum menunjukkan mana yang baik dan mana yang buruk, hukum juga memberi petunjuk, sehingga segala sesuatunya itu dapat berjalan dengan tertib dan teratur. Begitu pula hukum dapat memaksa agar hukum itu ditaati anggota masyarakat itu sendiri. (2) Sebagai sarana untuk mewujudkan keadilan sosial lahir dan batin. Hukum itu memiliki isi berupa Perintah dan larangan, hukum itu sifatnya memaksa, hukum mempunyai sanksi dan daya yang mengikat fisik dan Psikologis. Dikarenakan hukum memiliki isi dan sifat yang telah disebutkan, maka hukum dapat memberi keadilan, dalam arti dapat menentukan siapa yang salah, dan siapa yang benar, dapat memaksa agar peraturan dapat ditaati dengan ancaman sanksi bagi pelanggarnya. (3) Sebagai sarana penggerak pembangunan, daya mengikat dan memaksa dari hukum dapat digunakan atau di daya gunakan untuk menggerakkan pembangunan, di sini hukum dijadikan alat untuk membawa masyarakat ke arah yang lebih maju. (4) Sebagai fungsi kritis. Menurut Soedjono Dirdjosisworo dalam bukunya pengantar ilmu hukum, hal 155 mengatakan: "Dewasa ini sedang berkembang suatu pandangan bahwa hukum mempunyai fungsi kritis, yaitu daya kerja hukum tidak semata-mata melakukan pengawasan pada aparatur pemerintah (petugas) saja melainkan aparatur penegak hukum termasuk di dalamnya". ${ }^{1}$ (5) Sebagai penentuan alokasi wewenang, maksudnya secara terperinci siapa yang boleh melakukan pelaksanaan (penegak) hukum, siapa yang harus menaatinya, siapa yang memilih sanksi yang tepat dan adil, seperti konsep hukum konstitusi negara. (6) Sebagai alat penyelesaian sengketa, seperti contoh persengketaan harta waris dapat segera selesai dengan ketetapan hukum waris yang sudah diatur dalam hukum perdata. (7) Memelihara kemampuan masyarakat untuk menyesuaikan diri dengan kondisi

\footnotetext{
${ }^{1}$ Soedjono Dirdjosisworo, 2008, Pengantar Ilmu Hukum, Rajawali Pers, Jakarta, Hlm. 155
} 
kehidupan yang berubah. Yaitu dengan cara merumuskan kembali hubunganhubungan esensial antara anggotaanggota masyarakat. Seperti diketahui bahwa di dalam setiap masyarakat senantiasa terdapat berbagai kepentingan dari warganya. Di antara kepentingan itu ada yang bisa selaras dengan kepentingan yang lain, tetapi ada juga kepentingan yang memicu konflik dengan kepentingan yang lain. Untuk keperluan tersebut, hukum harus difungsikan menurut fungsifungsi tertentu untuk mencapai tujuannya. Dengan kata lain, fungsi hukum adalah menertibkan dan mengatur pergaulan dalam masyarakat serta menyelesaikan konflik yang terjadi.

Dari sekian banyak peranan dan fungsi hukum, maka tujuan dari perwujudan hukum itu haruslah ada, maka tujuan hukum juga terjadi perbedaan pendapat antara satu ahli dengan ahli yang lain. Kansil mengemukakan beberapa pendapat ahli hukum tentang tujuan hukum: ${ }^{2}$

\section{Prof. Lj. Van Apeldorn}

Dalam bukunya "Inleiding tot de studie van het Nederlandse recht" mengatakan bahwa tujuan hukum adalah mengatur tata tertib dalam masyarakat secara damai dan adil. ${ }^{3}$ Demi mencapai kedamaian hukum harus diciptakan masyarakat yang adil dengan mengadakan perimbangan antara kepentingan yang bertentangan satu sama

2 Kansil, C.S.T, 1986, Pengantar Ilmu Hukum dan Tata Hukum Indonesia, Balai Pustaka, Jakarta, Hlm. 41

${ }^{3}$ Lj.Van Apeldorn, 1984, Inleiding, INDHill.co, Jakarta, Hlm. 151 lain, dan setiap orang harus memperoleh (sedapat mungkin) apa yang menjadi haknya. Pendapat Apeldorn ini dapat dikatakan jalan tengah antara dua teori tujuan hukum, teori etis dan utilitis.

2. Aristoteles

Dalam Bukunya "Rhetorica" mencetuskan teorinya bahwa tujuan hukum menghendaki keadilan sematamata dan isi daripada hukum ditentukan oleh kesadaran etis mengenai apa yang dikatakan adil dan apa yang dikatakan tidak adil. ${ }^{4}$ Menurut teori ini buku mempunyai tugas suci dan luhur, ialah keadilan dengan memberikan tiap-tiap orang apa yang berhak dia terima yang memerlukan peraturan sendiri bagi tiap-tap kasus.

Apabila ini dilaksanakan maka tidak akan ada habisnya. Oleh karenanya Hukum harus membuat apa yang dinamakan "Algemeene Regels" (Peraturan atau ketentuan-ketentuan umum. Peraturan ini diperlukan oleh masyarakat teratur demi kepentingan kepastian Hukum, meskipun pada sewaktu- waktu dapat menimbulkan ketidak adilan.

\section{Prof. Soebekti SH}

Menurut Prof. Subekti SH keadilan berasal dari Tuhan YME dan setiap orang diberi kemampuan, kecakapan untuk meraba dan

\footnotetext{
${ }^{4}$ Aristoteles, 1980, Rhetorica, Balai Pustaka, Jakarta, Hlm. 18
} 
merasakan keadilan itu. ${ }^{5}$ Dan segala apa yang di dunia ini sudah semestinya menimbulkan dasar-dasar keadilan pada manusia. Dengan demikian, hukum tidak hanya mencarikan keseimbangan antara pelbagai kepentingan yang bertentangan satu sama lain, akan tetapi juga untuk mendapatkan keseimbangan antara tuntutan keadilan tersebut dengan "Ketertiban" atau "Kepastian Hukum”.

"Dasar-dasar Hukum dan Pengadilan" mengemukakan bahwa tujuan hukum adalah melayani kehendak negara yakni mendatangkan kemakmuran dan kebahagiaan pada rakyat. Dalam melayani tujuan negara, hukum akan memberikan keadilan dan ketertiban bagi masyarakatnya.

Dari penjelasan dan uraian di atas maka dalam artikel ini penulis dapat mengambil suatu pokok permasalahan adalah bagaimana usaha-usaha memasyarakatkan hukum di dalam masyarakat agar sesuai dengan fungsi dan tujuan hukum dan apa saja yang menjadi hambatan dalam memasyarakatkan hukum di dalam masyarakat.

\section{METODE PENELITIAN}

Penelitian ini merupakan penelitian deskriptif. Di dalam penelitian ini, penulis menggambarkan secara umum tentang usaha-usaha memasyarakatkan hukum di dalam masyarakat, terutama hal-hal yang menyangkut usaha penegakan hukum.

5 Subekti, 1955, Dasar-Dasar Hukum dan Pengadilan. Soeroengan, Jakarta, Hlm. 131
Data dikumpulkan melalui penelitian kepustakaan dengan melihat permasalahan yang terjadi di lapangan dan memperhatikan teori yang ada. Kemudian, data dianalisis sesuai dengan teori yang digunakan di dalam penelitian ini. Berdasarkan penelitian yang sudah dilaksanakan, diperoleh hasil penelitian yang akan dijelaskan di bagian pembahasan selanjutnya.

\section{HASIL DAN PEMBAHASAN}

Hasil yang diperoleh setelah melakukan penelitian pada umumnya untuk bisa memasyarakatkan hukum di dalam masyarakat sangat bergantung pada individu (subjek hukum) itu sendiri, maksudnya adalah tingkat kemauan, kesadaran dan rasa ingin tahu adalah syarat mutlak yang harus dimiliki agar bisa terwujudnya hukum di dalam masyarkat. Sedangkan pendidikan adalah pondasi dasar yang juga memiliki peranan sangat penting untuk memberi pemahaman dari rasa ingin tahu akan individu atas hukum yang berlaku tumbuh dan berkembang di dalam masyarakat dengan melalui pendidikan subjek hukum akan dituntun dan diarahkan dapat mengetahui dan memahami serta menjalankan hukum sesuai dengan fungsi dan tujuan hukum yang telah diterangkan sebelumnya, tanpa pendidikan maka akan terasa sangat sulit untuk bisa memasyarakatkan hukum di dalam masyarakat.

Usaha-usaha lain dalam memasyarakatkan hukum di dalam masyarakat adalah dengan lebih banyak memberikan penyuluhan, pelatihan, 
sosialisasi dan seminar-seminar yang menyangkut persoalan hukum, karena dengan banyaknya penyuluhan, pelatihan dan seminar yang menyangkut persoalan hukum akan lebih memberi pengkayaan dan pemahaman kepada masyarakat akan arti pentingnya hukum itu dimasyarakatkan. Sehingga masyarakat dengan sendirinya akan dapat merasakan langsung manfaat jika hukum itu dijalankan sesuai dengan fungsi dan tujuan yang telah ditetapkan.

Adat dan kebudayaan akan menjadi bumerang yang sangat kuat jika hendak memasyarakatkan hukum di dalam masyarakat secara umum, karena dari hasil penelitian yang dilakukan kecenderungan masyarakat hanya lebih mengetahui hukum adat yang tumbuh dan berkembang di masyarakat ketimbang hukum lainnya. Hal ini sangat menjadi hambatan dalam memasyarakatkan hukum di dalam masyarakat, karena mereka akan sangat mudah tunduk dan taat akan perintah hukum adat ketimbang hukum yang lainnya. Budaya setempat yang mempengaruhi mereka untuk selalu taat dan patuh terhadap hukum adat, bagi mereka semenjak mereka lahir bahkan semenjak nenek moyang mereka hanya melestarikan hukum adat, sehingga hukum yang lainnya dianggap tidak berguna dan dipandang sebelah mata. Padahal dari fungsi dan tujuan hukum sangat jelas akan arti pentingnya hukum secara umum untuk dapat diterapkan di dalam masyarakat karena selain akan menyelesaikan persoalan yang adat juga akan menyelesaikan persoalan lainnya.
Sarana dan prasarana merupakan hambatan yang sering ditemukan di lapangan dalam upaya memasyarakatkan hukum di dalam memasyarakat, ketiadaan sarana dan prasarana menjadi alasan klasik bagi masyarakat untuk mengetahui dan mendalami pengetahuan hukum secara umum, adapun sarana yang dimaksud dalam artikel ini antara lain: buku bacaan pendukung yang menyangkut tentang persoalan hukum, wadah atau tempat berkumpul masyarakat dalam menerima penyuluhan hukum, petugas yang menjadi tenaga penyuluh hukum, media masa baik itu media elektronik, media komunikasi dan juga media cetak. Selain itu sarana transportasi juga menjadi kendala dalam usaha-usaha memasyarakatkan hukum di dalam masyarakat, kelancaran transportasi dan komunikasi menjadi bagian penting untuk memudahkan akses dalam memahami dan mempelajari serta mengetahui perkembangan hukum yang ada di masyarakat, sehingga dengan kelancaran transportasi dan komunikasi akan memberikan peluang kepada subjek hukum untuk melihat dan mengetahui kemajuan hukum di daerah lain dan dapat membandingkan dengan tempat mereka berada serta dapat melakukan dan memberi warna perubahan hukum ke arah lebih maju demi terwujudnya hukum yang sesuai dengan tujuan dan fungsi hukum itu sendiri.

Struktur hukum merupakan hambatan yang tidak terlepas dalam usaha-usaha memasyarakatkan hukum di dalam masyarakat, struktur hukum yang 
dimaksud dalam artikel ini adalah masih banyak tumpang tindihnya suatu aturan yang masih berlaku di dalam masyarakat terutama hukum adat mendominasi ketimbang aturan lainnya, sehingga hukum adat menjadi super power terhadap hukum lainnya. Di lain sisi ketidak pahaman akan tumpang tindihnya fungsi dan tujuan antara hukum agama dengan hukum adat yang sering kali dalam pelaksanaannya tidak jelas mana yang hukum adat dan mana yang hukum agama. Sebagai contoh dalam persoalan waris masyarakat kebingungan mau menggunakan hukum adat atau menggunakan hukum agama, padahal keduanya memiliki peranan yang sama yaitu sama-sama hukum positif yang sedang berlaku di suatu negara. Sehingga hukum adat atau hukum agama yang akan digunakan memiliki kekuatan yang mengikat satu sama lainnya, tetapi dalam aturan yang semestinya masyarakat harus diberikan pemahaman kapan harus menggunakan kontek hukum adat dan kapan pula harus menggunakan kontek hukum agama.

Hambatan lain dalam usaha-usaha memasyarakatkan hukum di dalam memasyarakat adalah aparat penegak hukum itu sendiri, sering kali kita temukan dalam artikel ini aparat penegak hukum tidak bisa memberikan contoh tauladan yang baik dalam usaha-usaha memasyarakatkan hukum di dalam masyarakat, mereka yang seharusnya menjadi contoh tauladan dan ujung tombak dari penegakan hukum malahan terbalik mereka pula yang menjadi busur penghancur akan jalannya hukum di masyarakat.

Sebagai contoh keluhan masyarakat yang peneliti temui dalam artikel ini menyangkut aparat penegak hukum diantaranya: pelanggaran lalu lintas seringkali terjadinya tebang pilih dalam proses penertibannya, masih banyak aparat itu sendiri yang melakukan pelanggaran. Pada aparat hukum adat ditemukan dalam artikel ini mereka yang seyogyanya menjadi panutan tapi sering kali mereka dalam menetapkan sanksi adat tidak sesuai dengan yang seharusnya, misalnya ketika yang melakukan pelanggaran masih ada hubungan keluarga maka sanksi adatnya akan bisa diringankan tetapi lain halnya jika yang melakukan pelanggaran adat tidak ada hubungan kekeluargaan maka akan lain pula sanksi yang akan diterapkan.

Dari pembahasan di atas dapat disimpulkan bahwa hasil yang ditemukan dalam penelitian ini membuktikan bahwa dalam usaha memasyarakatkan hukum di dalam masyarakat dibutuhkan banyak hal diantaranya: kemauan dan rasa ingin tahu, pendidikan, dukungan dari lingkungan adat dan budaya serta kesadaran untuk taat dan patuh terhadap hukum yang berlaku di masyarakat dengan ikhlas dan tanpa paksaan dari siapapun juga, selain hal tersebut penyuluhan, sosialisasi dan juga seminar menjadi alat untuk memudahkan memasyarakatkan hukum di dalam masyarakat. Sedangkan yang menjadi hambatan dalam usaha memasyarakatkan hukum di dalam masyarakat di dominasi oleh tingkat 
pendidikan dan pengetahuan yang dimiliki oleh masyarakat, adat dan budaya setempat yang tumbuh dan berkembang sangat diyakini adalah satusatunya hukum yang mereka miliki, dan juga struktur hukum, serta aparatur penegak hukum itu sendiri dan juga substansi hukum.

\section{SIMPULAN}

Kesimpulan berdasarkan hasil penelitian yang telah dilakukan dengan menganalisis persoalan yang ada maka dapat ditarik suatu kesimpulan yang menjadi usaha-usaha dalam proses memasyarakatkan hukum di dalam masyarakat adalah dengan cara pendidikan dan penanaman rasa ingin tahu pada subjek hukum, selain itu ketersediaan sarana dan prasarana pendukung sangat memberikan peranan penting dalam memudahkan subjek hukum untuk mempelajari, mendalami dan mengetahui tentang persoalan hukum yang sedang dan atau akan terjadi di masa yang akan datang. Kegiatan penyuluhan dan seminar merupakan salah satu cara untuk lebih memudahkan masyarakat mengetahui tentang persoalan hukum, karena dengan adanya penyuluhan dan seminar tersebut masyarakat akan bisa bersosialisasi langsung dengan narasumber guna mendapatkan tambahan ilmu dan saling bertukar pikiran. Adapun yang menjadi hambatan dalam usaha- usaha memasyarakatkan hukum di dalam masyarakat antara lain stuktur hukum yang masih tumpang tindih satu dengan yang lainnya, budaya hukum yang selalu memprioritaskan hukum adat diatas hukum yang lainnya serta kecenderungan mempertahankan hukum adat walaupun pada dasarnya hukum tersebut sudah tidak relevan dengan kebutuhan hukum dan atau persoalan hukum yang sedang dihadapi dan akan dihadapi untuk masa yang akan datang, karena pada hakikatnya hukum itu dinamis ia harus bergerak mengikuti kebutuhan dan perkembangan subjek hukum.

\section{DAFTAR PUSTAKA}

Aristoteles. 2016. Rhetorica.

Dirdjosisworo, Soedjono. 2008. Pengantar Ilmu Hukum. Rajawali Pers, Jakarta.

Kansil, C.S.T. 1986. Pengantar Ilmu Hukum dan Tata Hukum Indonesia. Balai Pustaka, Jakarta.

Kansil, C.S.T dan Kansil, Cristine. 2003. Pengantar Hukum Indonesia. Balai Pustaka, Jakarta.

Lj Van Apeldorn. 1985. Pengantar Ilmu Hukum. Pradnya Paramita, Jakarta.

Subekti. 1972. Law in Indonesia. PT Karya Nusantara, Jakarta.

Subekti. 1955, Dasar-Dasar Hukum dan Pengadilan. Soeroengan, Jakarta. 